\title{
Dart Device
}

National Cancer Institute

\section{Source}

National Cancer Institute. Dart Device. NCI Thesaurus. Code C149425.

A pointed missile which on contact with an animal delivers its medicinal content. 